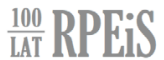

\section{POZNAŃSKA NAUKA PRAWA MIĘDZYNARODOWEGO NA LAMACH „RUCHU PRAWNICZEGO, EKONOMICZNEGO I SOCJOLOGICZNEGO”}

W kwietniu 2019 r. Wydział Prawa i Administracji Uniwersytetu im. Adama Mickiewicza w Poznaniu świętował setną rocznicę. Dziśs - dwa lata po tym jubileuszu - swoje święto obchodzi poznańskie czasopismo, którego początki sięgają 1921 r.: „Ruch Prawniczy, Ekonomiczny i Socjologiczny”. Jest on nie tylko jedną z najważniejszych wizytówek Wydziału, lecz także szczególną instytucja, która reprezentuje kapitał symboliczny wielu pokoleń prawników, ekonomistów i socjologów. Część tego kapitału stanowią prace czołowych przedstawicieli polskiej nauki prawa międzynarodowego. Na łamach Ruchu gościli bowiem Zygmunt Cybichowski, Ludwik Ehrlich, Julian Makowski, Władysław Namysłowski oraz Szymon Rundstein ${ }^{1}$. Publikowali w nim także Marian Iwanejko, Kazimierz Kocot, Stanisław E. Nahlik, Janusz Symonides oraz Remigiusz Zaorski². W gronie jego autorów znaleźli się również prawnicy internacjonaliści, reprezentujący poznańską Katedrę Prawa Międzynarodowego. Próba usystematyzowania prac, które publikowali oni na łamach minionych odsłon RPEiS, stanowi cel niniejszego studium.

\section{HISTORIA POZNAŃSKIEJ SZKOLY PRAWA MIĘDZYNARODOWEGO}

Rozwój kierunków badań prowadzonych przez przedstawicieli poznańskiej nauki prawa międzynarodowego wyznaczają prace naukowe trzech

" Paweł Kwiatkowski, Uniwersytet Gdański, pawel.kwiatkowski@prawo.ug.edu.pl, https://orcid.org/0000-0003-2567-6819, Redaktor naczelny czasopisma „Adam Mickiewicz University Law Review”.

${ }^{1}$ Cybichowski (1930); Ehrlich (1959); Makowski (1936); Namysłowski (1933); Rundstein (1928).

${ }^{2}$ Iwanejko (1961), (1962), (1972); Kocot (1961); Nahlik (1964); Symonides (1966), (1970); Zaorski (1963). 
pokoleń prawników internacjonalistów. Ich inicjatorem, a zarazem twórcą Katedry Prawa Międzynarodowego był Bohdan Winiarski - autorytet $\mathrm{w}$ dziedzinie prawa wodnych szklaków komunikacyjnych, polityk oraz pierwszy polski sędzia i prezes Międzynarodowego Trybunału Sprawiedliwości. Jego następca Alfons Klafkowski zapisał się w historii nauk prawnych jako twórca poznańskiej szkoły prawa międzynarodowego i organizator życia naukowego Katedry. Okres, w którym kierował on tą jednostka, pozwolił na rozwój jej programu naukowego o nowe kierunki badań. Sam Klafkowski skoncentrował się na prawnomiędzynarodowym ujęciu stosunków polsko-niemieckich. Uzupełnieniem podjętej przez niego problematyki stały się tematy zaproponowane przez jego współpracowników - Krzysztofa Skubiszewskiego, który rozwinął dorobek Katedry o studia nad prawem organizacji międzynarodowych, odpowiedzialnością międzynarodową i użyciem siły w stosunkach międzynarodowych, oraz Bolesława Wiewióry, który poświęcił uwagę zagadnieniu terytorium. Listę tych tematów poszerzyli następnie uczniowie Klafkowskiego i Skubiszewskiego - Jan Sandorski, Jerzy Tyranowski i Tadeusz Gadkowski, dodając do niej prawnomiędzynarodowe aspekty integracji gospodarczej, problematykę nieważność umów międzynarodowych, zagadnienie sukcesji w prawie międzynarodowym, prawo dyplomatyczne oraz międzynarodowe prawo atomowe. Dalszy rozwój Katedry o studia nad międzynarodowym prawem praw człowieka zainicjowała z kolei Anna Michalska, która przez trzydzieści lat pełniła funkcję sekretarza redakcji RPEiS.

O przedmiocie badań prowadzonych przez grono poznańskich internacjonalistów na łamach Ruchu pisze Klafkowski we Współczesnych tendencjach rozwojowych prawa międzynarodowego ${ }^{3}$, gdzie wyróżnia on trzy główne kierunki zmian zachodzących w strukturze ponadnarodowego ładu normatywnego. Pierwszy łączy z rozwojem społeczności międzynarodowej, który rzutuje na proces tworzenia prawa międzynarodowego i jego źródeł, prowadząc do wzrostu znaczenia traktatów. Drugi wiąże z wolą przeksztalcenia prawa międzynarodowego $\mathrm{w}$ wyłącznego regulatora pokojowych stosunków pomiędzy państwami, co znajduje oparcie w postanowieniach Karty Narodów Zjednoczonych. Trzeci zaś z rozszerzeniem zakresu zastosowania prawa międzynarodowego o przestrzeń kosmiczną. Analizując wyróżnione tendencje, Klafkowski odkrywa zarazem społeczne uwarunkowania tej gałęzi prawa, które rzutuje na podejście poznańskich internacjonalistów.

Kierunki badań reprezentatywne dla poznańskiej nauki prawa międzynarodowego znajdują odzwierciedlenie $\mathrm{w}$ tekstach jej przedstawicieli, które ukazywały się regularnie na łamach RPEiS. Są to prace poświęcone studiom nad relacja pomiędzy prawem międzynarodowym a prawem krajowym, źródłami prawa międzynarodowego, międzynarodowym prawem wodnych szlaków komunikacyjnych, międzynarodowym prawem konfliktów zbrojonych i od-

\footnotetext{
${ }^{3}$ Klafkowski (1963).
} 
powiedzialnością międzynarodową, prawem organizacji międzynarodowych, międzynarodowa ochroną praw człowieka, terytorium i uznaniem w prawie międzynarodowym oraz prawem atomowym.

\section{PRAWO MIĘDZYNARODOWE A PRAWO KRAJOWE}

Zagadnienie relacji pomiędzy prawem krajowym a prawem międzynarodowym funkcjonuje w tekstach poznańskich internacjonalistów na dwóch poziomach rozważań. Pierwszy obejmuje ogólne rozważania nad Wzajemnym stosunkiem $i$ zwiazkami pomiędzy prawem międzynarodowym $i$ prawem krajowym w tekście Skubiszewskiego ${ }^{4}$. Drugi odwołuje się do analizy tej relacji na przykładzie państwa polskiego w tekstach Skubiszewskiego i Klafkowskiego. W pracy Prawo PRL a traktaty ${ }^{5}$ Skubiszewski poświęca uwagę ocenie stanu „reglamentacji stosunku pomiędzy prawem PRL a traktatami, których państwo polskie jest strona", dokonywanej z perspektywy początku lat siedemdziesiątych minionego stulecia. W ocenie tej, poprzedzonej teoretycznym wstępem, uwzględnia miejsce traktatów w Konstytucji PRL, miejsce traktatów w świetle ustaw PRL oraz zagadnienie kolizji pomiędzy traktatem a prawem PRL. Całość wieńczy natomiast trzema postulatami de lege ferenda. W pierwszym wskazuje na potrzebę uregulowania zagadnienia stosowania traktatów w krajowym porządku prawnym, której odpowiada norma o następującej treści: „Organa administracji i gospodarki państwowej oraz sądy i komisje arbitrażowe stosują zwyczajowe prawo międzynarodowe i traktaty wiążące PRL” Drugi wiąże z nadaniem sejmowi kompetencji związanych z procesem wiązania się postanowieniami wybranych traktatów przez państwa, dla którego proponuje normę w następującym brzmieniu: „Zgoda PRL na związanie się traktatem, którego przedmiot reguluja ustawy, podlega uprzedniej aprobacie sejmu"8. Trzeci natomiast odnosi do sposobu rozstrzygania konfliktu pomiędzy prawem krajowym a międzynarodowym, czego wyrazem jest norma „Przepis międzynarodowego prawa zwyczajowego lub traktatu wiążącego PRL przeważa w przypadku, gdy ustawa lub wszelki inny akt oparty na ustawie nie da się pogodzić z tym przepisem"9.

W tekście Umowa międzynarodowa a ustawa ${ }^{10}$ Klafkowski w trzech punktach rozważa zagadnienie kolizji pomiędzy normami prawa międzynarodowego publicznego a prawem krajowym, sięgając po przykład polskiego porządku prawnego, którego ramy wyznacza Konstytucja z 1952 r. Pierwszy obejmuje analizę głównych założeń metodologicznych podjętej tematyki badawczej.

\footnotetext{
${ }^{4}$ Skubiszewski (1986).

5 Skubiszewski (1972).

6 Skubiszewski (1972).

7 Skubiszewski (1972).

8 Skubiszewski (1972).

9 Skubiszewski (1972).

10 Klafkowski (1965).
} 
Drugi koncentruje się na zasadzie unikania konfliktu ustawy z umową międzynarodowa. Trzeci natomiast łączy zagadnienie kolizji pomiędzy wyróżnionymi typami źródeł prawa z problematyką odpowiedzialności prawnomiędzynarodowej. Przyglądając się wyróżnionym punktom, Klafkowski dowodzi, że konflikt ustawy z umową międzynarodową może powstać tylko w systemie prawa wewnętrznego a zadanie polegające na jego wyeliminowaniu spoczywa na sądach i innych organach państwa.

\section{III. ŹRÓDŁA PRAWA MIĘDZYNARODOWEGO}

Uwagę zagadnieniu źródeł prawa międzynarodowego poświęcają Winiarski i Sandorski. Rozważania, które Winiarski prowadzi w tekście O kodyfikacji prawa międzynarodowego ${ }^{11}$, obejmują trzy punkty: wpływ pozaprawnych determinant na prace nad projektami kodyfikacyjnymi i ich przełożenie na porządek prawnomiędzynarodowy, koncepcje teoretyczne przemawiające za kodyfikacja prawa międzynarodowego oraz służące jej inicjatywy podejmowane na przestrzeni trzech pierwszych dekad XX stulecia. Pierwsze z wyróżnionych zagadnień Winiarski wiąże z dążeniem państw do niezależności, które przeciwstawia się ponadnarodowej wizji jedności politycznej, ograniczając zarazem proces rozwoju prawa międzynarodowego. Drugie łączy z projektami - Benthama, Traitteur-Luzberga, de Ferratera, Gardena, Weissa, Domin-Petrushevecza, Liebery, Bluntschliego oraz Przesmyckiego. Trzecie z kolei śledzi aktywność społeczności międzynarodowej w kreowaniu umownego prawa międzynarodowego, konfrontując inicjatywy europejskie i amerykańskie z projektami o uniwersalnym charakterze. Analizując inicjatywy europejskie, Winiarski zwraca uwagę na szereg prób podejmowanych na rzecz uregulowania pokojowego rozstrzygania sporów międzynarodowych, ekstradycji, żeglugi na rzekach, prawa morskiego oraz międzynarodowego prawa prywatnego. Analizując amerykańską aktywność na tym polu, zwraca uwagę na kongresy w Limie z 1877 i Montevideo z 1888 r. oraz sześć konferencji panamerykańskich, które w latach 1889-1928 odbyły się, kolejno, w Waszyngtonie, Meksyku, Rio de Janeiro, Buenos-Aires, Santiago i Hawanie. Szansę na przełamanie tego euroamerykańskiego zróżnicowania w podejściu do kodyfikacji prawa międzynarodowego upatruje natomiast w działalności Ligii Narodów, która poszukuje uniwersalnej formuły dla rozwoju prawa międzynarodowego.

Analizując wpływ przymusu na ważność umów międzynarodowych, Sandorski odwołuje się do rozróżnienia pomiędzy zastosowaniem przymusu fizycznego i psychicznego wobec przedstawiciela państwa a przymusem wobec państwa ${ }^{12}$. Przesłanki te rozpatruje z kolei przez pryzmat historii prac nad

\footnotetext{
11 Winiarski (1930).

12 Sandorski (1972).
} 
Konwencją wiedeńską o prawie traktatów z 1969 r. Historia ta ujawnia bowiem różnice w podejściu poszczególnych przedstawicieli społeczności międzynarodowej do wyróżnionych przesłanek nieważności umowy międzynarodowej, które rzutują na stan przestrzegania prawa międzynarodowego. Śledząc wpływ tych stanowisk na proces kodyfikacji prawa traktatów, Sandorski przygląda się dwóm zwyczajowym normom tego porządku prawnego, by następnie zestawić je z treścią analizowanej konwencji. Pierwsza z wyróżnionych norm, zakazująca zastosowania nielegalnej formy przymusu fizycznego i psychicznego wobec przedstawicieli państwa, znana jest prawu międzynarodowemu od wieków. Drugiej natomiast towarzyszy szereg pytań o jej status. Obydwie jednak - jak zauważa Sandorski - wprowadzono ostatecznie do tekstu Konwencji wiedeńskiej o prawie traktatów.

\section{MIĘDZYNARODOWE PRAWO WODNYCH SZLAKÓW KOMUNIKACYJNYCH}

Szczególne miejsce w dorobku Winiarskiego zajmują studia nad międzynarodowym prawem wodnych szlaków komunikacyjnych. Dziedzinie tej Winiarski poświęcił tekst o problematyce narodowości statków rzecznych oraz pracę na temat instytucji hipoteki rzecznej. Posłużył się nią również w charakterze przykładu w rozważaniach nad stosunkiem prawa międzynarodowego do prawa rzymskiego.

Prowadzoną na tle ustaleń pierwszej konferencji prawa rzecznego Ligii Narodów z 1930 r. analizę pojęcia narodowości statków rzecznych Winiarski poprzedza wstępem na temat różnic w sposobie regulowania tego trwałego węzła prawnego łączącego statek z państwem w prawie międzynarodowym i krajowym ${ }^{13}$. W uwagach tych wskazuje on na szereg odwołań do tej konstrukcji prawnej, które odnajduje w traktatach i uchwałach komisji międzynarodowych oraz wybranych źródłach prawa krajowego przełomu XIX i XX stulecia. Odpowiedź na owo zróżnicowanie stanowią postulaty pierwszej konferencji prawa rzecznego, dotyczące narodowości statków, które Winiarski ujmuje w trzech punktach. Pierwszy nakazuje wzajemne respektowanie bander statków przez układające się państwa. Drugi zakłada, że każdy ze statków może mieć jedynie jedną narodowość. Trzeci wprowadza wymóg prowadzenia rejestru swoich statków przez państwa, wraz z wzajemnym uznawaniem wypisów z owych rejestrów.

Na tle postulatów wysuniętych podczas obrad pierwszej konferencji prawa rzecznego Ligii Narodów z 1930 r. Winiarski analizuje także polskie regulacje prawne poświęcone instytucji hipoteki rzecznej ${ }^{14}$. Analiza ta ujawnia zróżnicowanie porządku prawnego państwa polskiego, które panuje w okresie dwu-

\footnotetext{
13 Winiarski (1931).

14 Winiarski (1933).
} 
dziestolecia międzywojennego. Szansę na zmianę tego stanu, naznaczonego podziałami z czasu zaborów, Winiarski upatruje w ujednoliceniu przepisów prawa krajowego i zaleca prawodawcy oparcie prowadzonych w tym zakresie prac legislacyjnych na propozycjach wysuniętych podczas obrad przywołanej konferencji genewskiej. Sugeruje przy tym zarówno Polsce, jak i pozostałym państwom słowiańskim przystapienie do Konwencji prawa rzecznego z $1930 \mathrm{r}$. W działaniu tym upatruje bowiem szansy na ożywienie żeglugi w tym rejonie Europy.

Po przykład prawa rzecznego Winiarski sięga także w rozważaniach nad stosunkiem prawa międzynarodowego do prawa rzymskiego ${ }^{15}$. Punktem wyjścia do polemiki z teoretykami, którzy w prawie rzymskim upatrują jednego ze źródeł prawa międzynarodowego publicznego, czyni słowa sekretarza stanu Jeffersona, wypowiedziane na poparcie amerykańskiego żądania otwarcia dla żeglugi dolnego odcinka i ujść rzeki Mississipi:

Prawo rzymskie, które, jak prawo każdego państwa, stawiało żeglugę rzeczną na gruncie prawa naturalnego, jak dla swych własnych obywateli, proklamując rzeki jako publiczne uznawało też, że prawo używania brzegów rzeki wynika z prawa korzystania z drogi wodnej ${ }^{16}$.

Rozwinięcie tego osiemnastowiecznego poglądu Winiarski odnajduje w myśli Edouarda Engelhardta i wzorowanych na niej koncepcjach z przełomu XIX i XX stulecia, które w Instytucjach Justyniana upatrują podstawy do uznania rzek za dobro wspólne. Jak pisze Engelhardt: „prawodawstwo rzymskie przyrównywało wodę bieżącą do powietrza i morza, więc do rzeczy, które są wspólne wszystkim i nie mogą nigdy być zmonopolizowane” ${ }^{17}$, a „nikt nie ma żadnego interesu w przywłaszczeniu sobie rzeczy niewyczerpanej i odnawiającej się nieustannie, której wszyscy potrzebują i z której każdy może korzystać, nie uszczuplając korzyści innych" ${ }^{18}$. Słowa te Winiarski poddaje krytycznej rewizji, podkreślając, że pojęcia zakodowane w Instytucjach Justyniana nie mają bezpośredniego przełożenia na kształt międzynarodowego prawa rzecznego. Wykazuje tym samym, że prawo rzymskie nie poddaje się uproszczonym analogiom, a każdą z łacińskich instytucji należy oceniać przez pryzmat kontekstu historycznego. Ta krytyczna analiza nie marginalizuje wpływu recepcji prawa rzymskiego na rozwój porządku międzynarodowego, a jedynie przestrzega przed tendencją zmierzająca „,do wypełniania, pod firmą prawa rzymskiego, tak zwanych luk w prawie międzynarodowym, np. przez stosowanie analogii, które z natury tego prawa może mieć bardzo ograniczone tylko znaczenie" ${ }^{19}$.

\footnotetext{
15 Winiarski (1934).

16 Winiarski (1934).

17 Cyt. za: Winiarski (1934).

18 Cyt. za: Winiarski (1934).

19 Winiarski (1934).
} 


\section{MIĘDZYNARODOWE PRAWO KONFLIKTÓW ZBROJNYCH I ODPOWIEDZIALNOŚĆ MIĘDZYNARODOWA}

Punktem wyjścia rozważań prowadzonych w tekście Uprawnienie państw do samoobrony a Karta Narodów Zjednoczonych ${ }^{20}$ Skubiszewski czyni dwa zagadnienia towarzyszące wykładni art. 51 Karty. Pierwsze dotyczy zakresu modyfikacji dotychczasowego sposobu uregulowania prawa do samoobrony przez Kartę. Drugie koncentruje się na podmiotowym aspekcie uprawnienia do samoobrony zbiorowej. Na podstawie ich analizy Skubiszewski formuje cztery wnioski. Pierwszy rezerwuje prawo do samoobrony indywidualnej dla państwa, które padło ofiarą napaści zbrojnej, podkreślając jednocześnie, że akcje o charakterze prewencyjnym nie mogą zostać określone tym mianem. Drugi wiąże się z wyłączeniem możliwości skorzystania z owego uprawnienia przez państwo członkowskie Organizacji Narodów Zjednoczonych w sytuacji, gdy naruszenie praw tego państwa przyjmuje postać inna niż napaść zbrojna. Trzeci wskazuje, że organizacja ta jest w stanie zapewnić, by państwa niebędąca jej członkami postępowały zgodnie z owymi wymogami „w stopniu koniecznym dla utrzymania międzynarodowego pokoju i bezpieczeństwa”. Czwarty natomiast wiąże się z legitymizacją zbiorowego wystapienia zbrojnego państw członkowskich ONZ w obronie innego państwa członkowskiego, które padło ofiara zbrojnej napaści, dopuszczając zarazem uprawnienie do podjęcia analogicznego działania dla państw niebędących członkami tej organizacji, na mocy paktu Brianda-Kellogga oraz art. 2 ust. 4 Karty.

W tekście Prawo wojny i neutralności w świecie wspótczesnym z 1967 r. ${ }^{21}$ Skubiszewski demaskuje dysonans pomiędzy normami międzynarodowego prawa konfliktów zbrojnych a praktyką państw. Dysonans ten wiąże on z rozwojem technologii wojskowej, który determinuje sposób prowadzenia wojny totalnej. Wojna totalna, tak jak i wojna globalna, wymyka się bowiem normom prawa międzynarodowego, które znajdują zastosowanie jedynie do konwencjonalnych metod prowadzenia działań zbrojnych. Skubiszewski nie poprzestaje jednak na tej konkluzji, a zmiany obowiąującego stanu rzeczy nie upatruje w rewizji prawa wojny i neutralności. Dostrzega je natomiast „w pokojowej współpracy i współistnieniu wszystkich państw, w rozbrojeniu powszechnym i całkowitym” oraz „rozbudowie środków służących pokojowemu rozstrzyganiu sporów międzynarodowych".

W tekście Umowy sojusznicze Polski a Karta Narodów Zjednoczonych ${ }^{22}$ Skubiszewski analizuje traktatowe podstawy organizacji indywidualnej i zbiorowej samoobrony państwa polskiego. Czyniąc przedmiotem analizy polskie sojusze z lat 1945-1949, porównuje postanowienia wielostronnego Układu o przyjaźni, współpracy i pomocy wzajemnej z 14 maja 1955 r. i dwustronnych układów o przyjaźni, współpracy i pomocy wzajemnej ze Związkiem Radzieckim, Czechosłowacją, Bułgaria, Węgrami i Rumunią z wymogami stawianymi

\footnotetext{
${ }^{20}$ Skubiszewski (1962).

21 Skubiszewski (1967).

22 Skubiszewski (1959).
} 
przez art. 51 Karty. Zwraca przy tym uwagę na sposób sformułowania casus foederis w wyróżnionych układach, nawiązania do Karty, którymi umowy te operuja, przyjęty w nich typ samoobrony oraz ich regionalny charakter. Rozważania, które prowadzi, wiodą natomiast do wniosku, że analizowane sojusze wyznaczaja podstawy organizacji indywidualnej i zbiorowej samoobrony państwa polskiego w zgodzie z systemem ONZ.

Rozważania nad organizacją systemu obrony państwa polskiego znajduja rozwinięcie w tekście Podstawy prawne bezpieczeństwa Polski2 ${ }^{23}$, w którym Klafkowski analizuje pozycję państwa polskiego w realiach powojennego ładu międzynarodowego połowy lat sześćdziesiątych, by następnie sformułować wnioski dotyczące interpretacji porozumień międzynarodowych określających tę pozycję na tle porozumień poczdamskich. Przedmiotem tego syntetycznego namysłu Klafkowski czyni dwa typy umów - umowy wielostronne oraz dwustronne. Pierwsza grupa obejmuje Kartę Narodów Zjednoczonych, Układ o przyjaźni, współpracy i pomocy wzajemnej z 14 maja 1955 r. oraz Układ o częściowym zakazie prób broni nuklearnej w atmosferze, w przestrzeni kosmicznej i pod wodą z 5 sierpnia 1963 r. Drugą natomiast tworza: bilateralne układy o przyjaźni, współpracy i wzajemnej pomocy, które w latach 1945-1949 Polska zawarła ze Związkiem Radzieckim, Jugosławia, Czechosłowacja, Bułgarią oraz Węgrami. Od ich interpretacji Klafkowski przechodzi do polityki państwa polskiego, wieńcząc prowadzone w tym zakresie rozważania o ocenę rosnącej aktywności państwa polskiego na rzecz tworzenia stref bezatomowych,

Na łamach RPEiS opublikowany został także fragment z dzieła Pieniqdz na terytorium okupowanym. Studium prawnomiędzynarodowe ze szczególnym uwzględnieniem praktyki niemieckiej Skubiszewskiego ${ }^{24}$, w którym wyjaśnia on, jak w prawie międzynarodowym kształtuje się odpowiedzialność państwa za pieniądz okupacyjny. Analizując przykłady postępowania wybranych państw na tle art. 3 IV Konwencji haskiej, Skubiszewski wykazuje, że przepis ten nie stanowi powszechnie respektowanej podstawy prawnej, określającej obowiązek pokrycia „równowartości wycofanych z obiegu monet i banknotów okupacyjnych". Analiza ta prowadzi do wniosku, że stan ten wpływa na różnice w podejściu do regulowania tej odpowiedzialności, która zależy od rozpatrywanego przypadku.

\section{PRAWO ORGANIZACJI MIĘDZYNARODOWYCH}

Tematykę organizacji międzynarodowych na łamach Ruchu rozwija Sandorski w czterech tekstach poświęconych Radzie Wzajemnej Pomocy Gospodarczej (RWPG) i Organizacji Narodów Zjednoczonych. W artykule na temat pozycji prawnej osób wchodzących w skład orangów RWPG Sandorski analizuje zakres przedmiotowy i podmiotowy przywilejów i immunitetów, z których

\footnotetext{
${ }^{23}$ Klafkowski (1964).

24 Skubiszewski (1960).
} 
korzystają zarówno przedstawiciele państw, jak i funkcjonariusze międzynarodowi ${ }^{25}$. Analizę tę poprzedza wstępem na temat struktury organizacyjnej i konstrukcji zdolności prawnej Rady, który czyni podstawą przyjętego rozróżnienia. Przedstawiciele pierwszej grupy, która obejmuje stałych przedstawicieli państw, ich zastępców, doradców oraz ekspertów, a także szefów, członków i sekretarzy delegacji wraz z ich doradcami i ekspertami, korzystają z immunitetu nietykalności osobistej, immunitetu od jurysdykcji organów sądowych co do wszystkich czynności wykonywanych w charakterze przedstawicieli, prawnej ochrony dokumentów, ulg celnych w stosunku do bagażu oraz zwolnień od wybranych świadczeń osobistych i podatków. Przedstawiciele drugiej grupy, obejmującej obywateli państw członkowskich organizacji, którzy z jej upoważnienia dokonują czynności służbowych, „nie podlegają odpowiedzialności sądowej i administracyjnej za wszelkie czynności wykonywane przez nich w charakterze funkcjonariuszy; są zwolnieni od świadczeń osobistych; sa zwolnieni od podatków bezpośrednich i potrąceń z poborów wypłacanych im przez Radę; maja prawo korzystania z takich ulg celnych w stosunku do ich bagażu osobistego, jakie przysługują odpowiadającym im ranga pracownikom przedstawicielstw dyplomatycznych w danym państwie”, a Sekretarzowi Rady i jego zastępcom przysługuja ponadto przywileje i immunitety przyznawane przedstawicielom dyplomatycznym w danym państwie.

Rozważania nad zasadami strukturalnymi RWPG Sandorski poświęca zasadzie jednomyślności i zasadzie braterskiej pomocy wzajemnej ${ }^{26}$. Pisząc o jednomyślności, podkreśla, że w zasadzie tej znajdują odzwierciedlenie trudności, które stają na przeszkodzie integracji pomiędzy państwami Rady. Zwraca także uwagę na brak środków prawnych, które umożliwiałyby skuteczne przełamanie sprzeciwu zainteresowanego państwa oraz ingerencję w zasadę braterskiej pomocy wzajemnej związaną z uznaniem za państwo zainteresowane negatywnie. Charakteryzując zasadę braterskiej pomocy wzajemnej, Sandorski wyróżnia natomiast punkty, które pozwalają na jej uściślenie. Do punktów tych zalicza obowiązek moralny „składania ofiar na rzecz jednego państwa przez inne" 27 wsparty autorytetem zasady internacjonalizmu socjalistycznego i powstrzymywanie się „od uniemożliwienia zawarcia umów oraz podjęcia uchwał, które są warunkiem prawidłowego rozwoju gospodarki narodowej innych państw członkowskich"28.

Poszukujac odpowiedzi na pytanie, czy instytucja kwestionowania pełnomocnictw w ONZ „może być jedynie zabiegiem, który ma chronić organizację przed działaniami rzekomych pełnomocników nie posiadajacych stosownych pełnomocnictw, czy też może być wyrazem sprzeciwu wobec władzy, która te pełnomocnictwa wystawiła" 29 , Sandorski odwołuje się do analizy przykładu węgierskiego, kongijskiego, jemeńskiego, kampuczańskiego oraz południowoafrykańskiego. Ich analiza prowadzi do przyjęcia trzech wniosków, prze-

\footnotetext{
25 Sandorski (1965).

26 Sandorski (1973).

27 Sandorski (1973).

28 Sandorski (1973).

29 Sandorski (1984).
} 
mawiających za krytyczną oceną praktyki, którą cechuje „niekonsekwencja, woluntaryzm, odstępstwa od litery prawa"30. Pierwszy wiązę się z politycznym charakterem instytucji zakwestionowania pełnomocnictwa, który wynika z przyjęcia Rezolucji Zgromadzenia Ogólnego ONZ 396 V z 14 grudnia 1950 r. Drugi dotyczy skutku, jaki wywiera jej zastosowanie w przypadku odrzucenia en bloc pełnomocnictw członków delegacji, który faktycznie jest tożsamy z zawieszeniem $\mathrm{w}$ prawach członka. Trzeci natomiast łączy próbę obejścia tych skutków z zastosowaniem przez Komitet Pełnomocnictw tzw. formuły węgierskiej, która umożliwia tymczasowy udział w sesjach ONZ bez zgłaszania dalszych sprzeciwów.

W krytycznym tekście na temat ONZ Sandorski przechodzi od przegladu wybranych uwag wysuwanych pod adresem tej instytucji do propozycji reform, przedstawionych w studium Sekretarza Generalnego z 1975 r. oraz raporcie Komitetu Specjalnego do Spraw Karty i Wzmocnienia Roli Organizacji z $1980 \mathrm{r} \cdot{ }^{31}$ Analizujac przywołane dokumenty po dziesięciu latach od inauguracji prac Komitetu Specjalnego do Spraw Karty i Wzmocnienia Roli Organizacji, zwraca uwagę na głosy krytyczne na temat składu i kompetencji Rady Bezpieczeństwa. Przygląda się także postulatowi utworzenia Specjalnego Komitetu do Spraw Operacji Pokojowych i Stałych Sił Zbrojnych w miejsce doraźnych kontyngentów narodowych. Zauważa przy tym, że postulaty te po upływie dziesięciu lat nie zostały zrealizowane, a klimat polityczny panujący $\mathrm{w}$ drugiej połowie lat osiemdziesiątych stoi na przeszkodzie urzeczywistnieniu celów służących umocnieniu pokoju na świecie. Zamiast zmian strukturalnych proponuje zatem, by aktywność ONZ ukierunkować na rozwiązania o charakterze pośrednim, które identyfikuje z rozwojem współpracy gospodarczej z państwami Południa. W poprawie sytuacji ekonomicznej upatruje bowiem szansy na opanowanie konfliktów, które trawią społeczność międzynarodowa, a z którymi ta społeczność, mająca do dyspozycji Radę Bezpieczeństwa, nie jest w stanie sobie poradzić.

\section{MIĘDZYNARODOWA OCHRONA PRAW CZLOWIEKA}

W cyklu prac z lat 1971-2001 Michalska podejmuje problematykę międzynarodowej ochrony praw człowieka. Cykl ten obejmuje teksty poświęcone aktywności wybranych instytucji w dziedzinie ochrony praw człowieka - Organizacji Narodów Zjednoczonych, Międzynarodowej Organizacji Pracy (MOP), Komitetu Praw Człowieka (KPC) i Organizacji Państw Amerykańskich (OPA). W jego skład wchodzą również prace na temat statusu Konwencji o ochronie praw człowieka i podstawowych wolności, Europejskiej karty społecznej, Międzynarodowego paktu praw obywatelskich i politycznych i Konwencji praw dziecka, a także artykuły poświęcone wybranym przykładom praw, które trak-

\footnotetext{
30 Sandorski (1984).

31 Sandorski (1988).
} 
taty te gwarantuja. Cykl wieńczą studia nad prawnymi i etycznymi aspektami inżynierii genetycznej, które Michalska pisze we współautorstwie z Tomaszem Twardowskim - biotechnologiem z Instytutu Chemii Bioorganicznej PAN.

Z zarysowanego przeglądu prac wyłaniają się cztery obszary tematyczne. Pierwszy, dotyczący instytucji międzynarodowych i związanych z nimi systemów ochrony praw człowieka, służy ocenie aktywności ONZ w kształtowaniu uniwersalnych standardów ochrony praw człowieka, której towarzyszy krytyczne ujęcie działalności na rzecz ich respektowania ${ }^{32}$; analizie ewolucji kompetencji Komitetu Praw Człowieka ONZ jako organu quasi-sądowego ${ }^{33}$ wraz z przedstawieniem instytucji zawiadomień indywidualnych ${ }^{34}$, synchronizacji uniwersalnego systemu ochrony praw człowieka z systemami regionalnymi ${ }^{35}$, prezentacji systemu MOP z uwzględnieniem obszaru ochrony wolności, równości szans i traktowania oraz godności i bezpieczeństwa ekonomicznego wraz z przyjętym modelem kontroli ${ }^{36}$ oraz analizie międzyamerykańskiego systemu ochrony praw człowieka w jego instytucjonalnym i materialnym wymiarze ${ }^{37}$. Drugi, poświęcony wybranym traktatom z dziedziny praw człowieka, obejmuje przegląd postanowień Konwencji o ochronie praw człowieka i podstawowych wolności ${ }^{38}$ i Europejskiej karty społecznej ${ }^{39}$, analize projektu Konwencji praw dziecka $^{40}$ oraz interpretację Międzynarodowego paktu praw cywilnych i politycznych w świetle raportów $\mathrm{KPC}^{41}$. Trzeci dotyczy wybranych praw i wolności - wolności związkowej ${ }^{42}$, prawa do życia ${ }^{43}$ oraz prawa do wyżywienia ${ }^{44}$. Czwarty natomiast przyjmuje postać interdyscyplinarnego dwugłosu na temat etycznych i prawnych aspektów inżynierii genetycznej ${ }^{45}$.

\section{TERYTORIUM I UZNANIE W PRAWIE MIĘDZYNARODOWYM}

Problematykę terytorium i uznania w prawie międzynarodowym rozwijaja Wiewióra i Tyranowski. Zagadnienie zwierzchnictwa terytorialnego Wiewióra rozpatruje na tle orzecznictwa Międzynarodowego Trybunału Sprawiedliwości z lat 1960-1962 ${ }^{46}$, czyniąc przedmiotem analizy trzy wybrane wyroki: z 12 kwietnia 1960 r. w sprawie Portugalii przeciwko Indiom; z 18 listopada

\footnotetext{
32 Michalska (1971), (1976).

33 Michalska (1996).

${ }^{34}$ Michalska (1989).

35 Michalska (1974).

${ }^{36}$ Michalska (1979).

${ }^{37}$ Michalska (1980).

38 Michalska (1978).

39 Michalska (1978).

${ }^{40}$ Michalska (1985).

${ }^{41}$ Michalska (1986).

${ }^{42}$ Michalska (1982).

${ }^{43}$ Michalska (1984).

${ }^{44}$ Michalska, Sandorski (1990).

45 Michalska, Twardowski (1998); Michalska, Twardowski (2000).

46 Wiewióra (1963).
} 
1960 r. w sprawie Hondurasu przeciwko Nikaragui oraz z 15 czerwca 1962 r. w sprawie Kambodży przeciwko Tailandii. Analizę tę Wiewióra poświęca czterem punktom. Pierwszy ukazuje skutki dorozumianego uznania jako podstawy tytułu terytorialnego. Drugi wskazuje, że forma ta „przesądza w sensie negatywnym możliwość dochodzenia roszczeń opartych na późniejszej negacji tego prawa". Trzeci poszukuje sposobu na rozstrzygnięcie konfliktu dwóch suwerenności. Czwarty natomiast dotyczy funkcji delimitacji, która - zdaniem Trybunału - jest czynnościa dodatkowa, niekonieczną dla ustalenia granic międzypaństwowych, chociaż jej przeprowadzenie „może spowodować zmiany linii granicznej ustalonej w sposób ogólny".

Rozpatrując zagadnienie nawiązania stosunków konsularnych w kontekście uznania międzynarodowego, Wiewióra sięga po przykład utworzenia konsulatu generalnego NRD w Kairze ${ }^{47}$, który ilustruje formę przejściową wiodąca do uznania. Jak pisze Wiewióra: „uznanie we wszystkich formach i postaciach, w jakich występuje, jest funkcją przede wszystkim polityczną i dlatego pozostawione jest swobodnej decyzji państwa”, a jego skutki prawne sa różne, w zależności od zakresu i przedmiotu. W praktyce międzynarodowej dostrzec można przykłady, które nie mieszczą się w ramach pełnych stosunków między państwami. Taki przejawy respektowania podmiotowości nowo utworzonego państw przed nawiązaniem formalnych stosunków Wiewióra wiąże właśnie z przykładem utworzenia konsulatu generalnego NRD.

Rozpatrując zagadnienie reintegracji terytorium państwa na tle prawa ludów do samostanowienia, Tyranowski sięga po analizę przykładów, które potwierdzają rozbieżności w podejściu Zgromadzenia Ogólnego ONZ do kwalifikacji wybranych przypadków ${ }^{48}$. Jak pisze Tyranowski: „w przypadku Hong Kongu i Makau Zgromadzenie Ogólne opowiadało się jednoznacznie za integralnością terytorialna państwa, w przypadku Timoru Wschodniego i Belize za prawem ludów tych terytoriów do samostanowienia i niepodległości; w przypadku Sahary Zachodniej za prawem do samostanowienia, ale bez podkreślania prawa do niepodległości; w odniesieniu do Falklandów i Gibraltaru nie było już mowy o prawie do samostanowienia, a jedynie nakłanianie zainteresowanych państw do uregulowania sytuacji na drodze dwustronnych negocjacji” ${ }^{49}$. Obserwacja ta wiedzie do przyjęcia trzech wniosków dotyczących roszczeń o reintegracji terytorium państwa. Po pierwsze, „roszczenia takie moga być zasadnie podniesione tylko przez państwo, które istniało w okresie ustanawiania władztwa kolonialnego lub ewentualnie przez jego bezpośredniego sukcesora. Po drugie, roszczenia w oparciu o dawne tytuły do suwerenności i w ramach dekolonizacji nie mają pierwszeństwa przed prawem ludu kolonialnego do niepodległości. Po trzecie, dopuszczalne sa te roszczenia o „reintegrację terytoriów kolonialnych, w przypadku których nie istnieje lud będacy nosicielem prawa do niepodległości”־0.

\footnotetext{
47 Wiewióra (1960).

48 Tyranowski (1988).

49 Tyranowski (1988).

50 Tyranowski (1988).
} 


\section{PRAWO ATOMOWE}

Cykl prac Gadkowskiego z lat 1981-1984, poświęconych prawu atomowe$\mathrm{mu}$, rozpoczyna przegląd wybranych systemów kontroli pokojowego wykorzystania energii atomowej ${ }^{51}$. W przegladzie tym Gadkowski przedstawia dwa przykłady systemów regionalnych - europejski i południowoamerykański, co uzupełnia o namysł nad systemami narodowymi, by następnie sformułować postulat dotyczący kontroli sprawowanej na poziomie międzynarodowym. Postulat ten nakazuje rozszerzenie przedmiotowego zakresu „międzynarodowej kontroli wykorzystania energii atomowej poprzez rozciagnięcie jej skutecznego działania na: wszystkie paliwa jądrowe, proces wzbogacania uranu, proces odzysku plutonu z reaktorów oraz pokojowe wybuchy jądrowe"52.

Analiza ograniczeń, którym podlega międzynarodowa kontrola działalności państw w zakresie zabezpieczenia pokojowego wykorzystania energii uzyskiwanej z paliw jądrowych, znajduje rozwinięcie w rozważaniach na temat porozumień o gwarancjach zawieranych pomiędzy Międzynarodowa Agencja Energii Atomowej (MAEA) a państwami członkowskimi ${ }^{53}$. Rozważania te pozwalają na sformułowanie wniosków dotyczących jej instytucjonalnych mechanizmów. Jak wykazuje Gadkowski, analizowany system podlega zarówno podmiotowym, jak i przedmiotowym ograniczeniom. Ograniczenia te wiąża się z celem i zakresem sprawowanej kontroli oraz uprawnieniami państw. Kontroli tej służą natomiast środki ujawniania i środki weryfikacji ${ }^{54}$, którym Gadkowski poświęca kolejny artykuł. Pierwszy typ obejmuje informacje i sprawozdania. Drugi natomiast przyjmuje postać inspekcji. Wyniki kontroli prowadzonej za pomocą wyróżnionych środków stanowią z kolei podstawę do dalszych działań, w tym także do nałożenia sankcji organizacyjnych i korygujących, określonych w art. XII.C Statutu MAEA.

Rozważania nad ramami prawnymi, służącymi zabezpieczeniu pokojowego wykorzystania energii atomowej, Gadkowski rozwija o ocenę skuteczności systemu kontroli wprowadzonego na mocy układu o nierozprzestrzenianiu broni jądrowej z $1968 \mathrm{r} \cdot{ }^{55}$ Analiza funkcji i procedury kontrolnej MAEA oraz istoty i treści porozumień o gwarancjach MAEA, prowadzona na tle postanowień tej umowy międzynarodowej, pozwala na sformułowanie sześciu wniosków. Pierwszy wiąże się postulatem, by układ o nierozprzestrzenianiu broni jądrowej z 1968 r. uczynić regulacją o uniwersalnym charakterze. Drugi nakazuje rozważenie możliwości ustalenia i przestrzegania szczególnie rygorystycznych zasad eksportu materiałów i urządzeń jądrowych do państw spoza układu. Trzeci zakłada, aby eksport ten wiązał się z koniecznościa poddania importera kontroli MAEA. Czwarty dotyczy ulepszenia systemu kontrolnego Agencji, tak by odpowiadał on rozwoju technologii. Piąty postuluje wprowadzenie

\footnotetext{
51 Gadkowski (1981).

52 Gadkowski (1981).

53 Gadkowski (1982).

54 Gadkowski (1984).

55 Gadkowski (1983).
} 
ograniczeń w zakresie wyposażania dla państw nieatomowych w „urządzenia pełnego cyklu paliwowego" wraz uszczelnieniem kontroli obrotu plutonem. Szósty łączy się z nakazem kontynuowania działań zmierzających do realizacji projektu stref wolnych od broni jądrowej.

\section{ZAKOŃCZENIE}

Historia, która „Ruch Prawniczy, Ekonomiczny i Socjologiczny” dzieli z przedstawicielami poznańskiej nauki prawa międzynarodowego, znajduje odzwierciedlenie w tekstach kilku pokoleń prawników internacjonalistów. Przegląd ich prac, prowadzony na tle głównych kierunków badań realizowanych w Katedrze Winiarskiego i jego następców, stanowi zarazem świadectwo przemian, które stały się udziałem rozważań nad prawem międzynarodowym. Rozważania te - zapisane na kartach minionych odsłon Ruchu - obejmuja studia Winiarskiego nad instytucją hipoteki rzecznej oraz statusem prawnym rzek, rozpatrywanym na tle zestawienia prawa rzymskiego z prawem międzynarodowym. Element tych rozważań stanowią także teksty poświęcone relacji pomiędzy prawem krajowym i międzynarodowym ${ }^{56}$; kodyfikacja prawa międzynarodowego ${ }^{57}$, nieważnością umów międzynarodowych ${ }^{58}$, użyciem siły w prawie międzynarodowym i odpowiedzialnością za pieniądz okupacyjny ${ }^{59}$, zasadom strukturalnym i członkom organów RWPG oraz krytyce wybranych instytucji $\mathrm{ONZ}^{60}$, systemom ochrony praw człowieka oraz etycznym i prawnym aspektom towarzyszącym rozwojowi inżynierii genetycznej ${ }^{61}$, terytorium i uznaniu międzynarodowemu ${ }^{62}$ oraz międzynarodowej kontroli pokojowego wykorzystania energii atomowej wraz z analizą układu o nierozprzestrzenianiu broni jądrowej63.

Spojrzenie na dorobek trzech pokoleń prawników internacjonalistów z poznańskiej Katedry Prawa Międzynarodowego z perspektywy roku 2021 - roku setnej rocznicy założenia „Ruchu Prawniczego, Ekonomicznego i Socjologicznego" - pozwala na nowo odczytać ich prace. W dorobku tym znalazły się zarówno teksty zakorzenione w kontekście historycznym, stanowiące świadectwo kierunków myślenia panujących $\mathrm{w}$ minionych odsłonach nauki prawa międzynarodowego, jak i publikacje, który zyskały ponadczasowy status. Charakter tych prac wpłynął na specyfikę współczesnej aktywności naukowej Katedry. Umiejętność łączenia teoretycznej pracy uniwersyteckiej z diagno-

\footnotetext{
56 Klafkowski (1965); Skubiszewski (1972), (1986).

57 Winiarski (1930).

58 Sandorski (1972).

59 Klafkowski (1964), Skubiszewski (1959), (1960), (1962), (1967).

60 Sandorski (1965), (1973), (1984), (1988).

${ }^{61}$ Michalska (1971), (1974), (1978), (1979), (1980), (1982), (1984), (1985), (1986), (1989), (1996); Michalska, Sandorski (1990); Michalska, Twardowski (1998), (2000).

62 Tyranowski (1988); Wiewióra (1960), (1963).

${ }^{63}$ Gadkowski (1981), (1982), (1983), 1984).
} 
zą bieżących potrzeb społeczności międzynarodowej i krajowej, która wyłania się z ich lektury, znajduje bowiem rozwinięcie w najnowszych tekstach, dotyczących takich zagadnień, jak prawo do samoobrony ${ }^{64}$, bezpieczeństwo międzynarodowe ${ }^{65}$ czy też uchwały organów organizacji międzynarodowych ${ }^{66}$. Przegląd dorobku trzech pokoleń poznańskich internacjonalistów mówi także wiele o „Ruchu Prawniczym, Ekonomicznym i Socjologicznym”, który obchodzi dziśs swoje święto. Analiza jego minionych wydań pozwala bowiem na ukazanie analogicznych historii do tej współtworzonej przez grono poznańskich internacjonalistów. Na jego łamach swoje własne historie odnajdą zapewne także przedstawiciele pozostałych nauk prawnych, ekonomiści i socjologowie, a symboliczny kapitał, który dzięki temu odkryja, pozwoli na sformułowanie kolejnych argumentów, przemawiajacych na rzecz Ruchu i jego twórców.

Buchowska, N. (2008). Wykonywanie kompetencji prawotwórczych przez organizacje międzynarodowe w ramach systemu contracting out. Ruch Prawniczy, Ekonomiczny i Socjologiczny 70(4): $29-45$.

Cybichowski, Z. (1930). Geneza i rozwój prawa międzynarodowego. Ruch Prawniczy, Ekonomiczny i Socjologiczny 10(1): $24 *-37 *$.

Diallo, B.S. (2013). Bezpieczeństwo zbiorowe a suwerenność państw. Ruch Prawniczy, Ekonomiczny i Socjologiczny 70(4): 37-50.

Ehrlich, L. (1930). Zasada czystych rąk w prawie mniejszościowem. Ruch Prawniczy, Ekonomiczny i Socjologiczny 10(1): $47 *-56 *$.

Ehrlich, L. (1959). Prawo obszarów morskich i podmorskich. Ruch Prawniczy i Ekonomiczny 21(4): 1-21.

Gadkowski, T. (1981). Kontrola regionalna i narodowa w systemie międzynarodowej kontroli pokojowego wykorzystania energii atomowej. Ruch Prawniczy, Ekonomiczny i Socjologiczny 43(3): 39-57.

Gadkowski, T. (1982). Porozumienia o gwarancjach Międzynarodowej Agencji Energii Atomowej. Ruch Prawniczy, Ekonomiczny i Socjologiczny 44(4): 143-161.

Gadkowski, T. (1983). Międzynarodowa kontrola nierozprzestrzeniania broni jądrowej. Ruch Prawniczy, Ekonomiczny i Socjologiczny 45(4): 97-115.

Gadkowski, T. (1984). Środki międzynarodowej kontroli pokojowego wykorzystania energii atomowej. Ruch Prawniczy, Ekonomiczny i Socjologiczny 46(3): 115-131.

Gadkowski, T. (2013). Problematyka samoobrony na tle zakazu użycia siły zbrojnej w prawie międzynarodowym. Ruch Prawniczy, Ekonomiczny i Socjologiczny 75(3): 5-20.

Iwanejko, M. (1961). Efekty jednolitych klauzul traktatowych. Ruch Prawniczy, Ekonomiczny i Socjologiczny 23(3): 111-130.

Iwanejko, M. (1962). Stanowisko portów morskich w świetle prawa międzynarodowego. Ruch Prawniczy, Ekonomiczny i Socjologiczny 24(3): 67-105.

Iwanejko, M. (1972). Spory międzynarodowe i potrzeba nowego podejścia do ich załatwiania środkami pokojowymi. Ruch Prawniczy, Ekonomiczny i Socjologiczny 34(3): 51-68.

Klafkowski, A. (1963). Współczesne tendencje rozwojowe prawa międzynarodowego. Ruch Prawniczy, Ekonomiczny i Socjologiczny 25(1): 1-20.

Klafkowski, A. (1964). Podstawy prawne bezpieczeństwa Polski. Ruch Prawniczy, Ekonomiczny i Socjologiczny 26(4): 17-34.

Klafkowski, A. (1965). Umowa międzynarodowa a ustawa. Ruch Prawniczy, Ekonomiczny i Socjologiczny 27(4): 1-19.
64 Gadkowski (2013).
65 Diallo (2013).
66 Buchowska (2008). 
Kocot, K. (1961) Kilka uwag z zakresu prawa narodów o pojęciu „nowych państw”. Ruch Prawniczy, Ekonomiczny i Socjologiczny 23(4): 81-92.

Makowski, J. (1930). Układy laterańskie wobec prawa narodów. Ruch Prawniczy, Ekonomiczny i Socjologiczny 10(1): $99^{*}-104^{*}$.

Makowski, J. (1936). O powstawaniu normy traktatowej. Ruch Prawniczy, Ekonomiczny i Socjologiczny 16(4): $321^{*}-343^{*}$.

Michalska, A. (1971). Międzynarodowa kontrola praw człowieka w Organizacji Narodów Zjednoczonych. Ruch Prawniczy, Ekonomiczny i Socjologiczny 33(2): 1-19.

Michalska, A. (1974). Uniwersalizm i regionalizm w międzynarodowej ochronie praw człowieka. Ruch Prawniczy, Ekonomiczny i Socjologiczny 36(2): 27-53.

Michalska, A. (1976). Międzynarodowa ochrona praw człowieka w trzydziestoleciu Organizacji Narodów Zjednoczonych. Ruch Prawniczy, Ekonomiczny i Socjologiczny 38(2): 1-16.

Michalska, A. (1978). Europejska Karta Społeczna. Ruch Prawniczy, Ekonomiczny i Socjologiczny 40(4): $75-85$.

Michalska, A. (1978). Europejska Konwencja Praw Człowieka. Ruch Prawniczy, Ekonomiczny i Socjologiczny 40(3): 21-35.

Michalska, A. (1979). Ochrona praw człowieka w ramach Międzynarodowej Organizacji Pracy. Ruch Prawniczy, Ekonomiczny i Socjologiczny 41(3): 17-44.

Michalska, A. (1980). Prawa człowieka w systemie Organizacji Państw Amerykańskich. Ruch Prawniczy, Ekonomiczny i Socjologiczny 42(2): 71-87.

Michalska, A. (1982). Międzynarodowa ochrona wolności związkowej. Ruch Prawniczy, Ekonomiczny i Socjologiczny 44(1): 85-99.

Michalska, A. (1984). Prawo do życia w traktatach międzynarodowych. Ruch Prawniczy, Ekonomiczny i Socjologiczny 46(3): 73-94.

Michalska, A. (1985). Międzynarodowa ochrona praw dziecka w ONZ. Ruch Prawniczy, Ekonomiczny i Socjologiczny 47(1): 1-17.

Michalska, A. (1989). Zawiadomienia indywidualne przed Komitetem Praw Człowieka. Ruch Prawniczy, Ekonomiczny i Socjologiczny 51(3): 35-51.

Michalska, A. (1986). Interpretacja Międzynarodowego paktu praw obywatelskich i politycznych w świetle raportów Komitetu Praw Człowieka. Ruch Prawniczy, Ekonomiczny i Socjologiczny 48(2): $1-29$.

Michalska, A. (1996). Ewolucja kompetencji Komitetu Praw Człowieka. Ruch Prawniczy, Ekonomiczny i Socjologiczny 58(1): 3-14.

Michalska, A., Sandorski, J. (1990). Międzynarodowa ochrona prawa do wyżywienia. Ruch Prawniczy, Ekonomiczny i Socjologiczny 52(2): 43-59.

Michalska, A., Twardowski, T. (1998). Człowiek i Prawne Aspekty Inżynierii Genetycznej. Ruch Prawniczy, Ekonomiczny i Socjologiczny 60(2): 77-92.

Michalska, A., Twardowski,T. (2000). Problemy Etyczne i Prawne Klonowania. Ruch Prawniczy, Ekonomiczny i Socjologiczny 62(4): 1-18.

Nahlik, S.E. (1964). Umowy międzynarodowe Polski Ludowej w okresie dwudziestolecia. Ruch Prawniczy, Ekonomiczny i Socjologiczny 26(4): 35-67.

Namysłowski, W. (1933). Istota i charakter prawa konsularnego. Ruch Prawniczy, Ekonomiczny i Socjologiczny 13(3): $123^{*}-134^{*}$.

Rundstein, S. (1928). Kodyfikacja prawa międzynarodowego. Ruch Prawniczy, Ekonomiczny i Socjologiczny 8(1): $1^{*}-43^{*}$.

Sandorski, J. (1965). Stanowisko prawne osób wchodzących w skład organów RWPG. Ruch Prawniczy, Ekonomiczny i Socjologiczny 27(1): 97-109.

Sandorski, J. (1972). Wpływ przymusu na nieważność umów międzynarodowych. Ruch Prawniczy, Ekonomiczny i Socjologiczny 34(2): 1-14.

Sandorski, J. (1973). O niektórych zasadach strukturalnych Rady Wzajemnej Pomocy Gospodarczej. Ruch Prawniczy, Ekonomiczny i Socjologiczny 35(3): 1-22.

Sandorski, J. (1984). Pełnomocnictwa w Organizacji Narodów Zjednoczonych. Ruch Prawniczy, Ekonomiczny i Socjologiczny 46(2): 119-135.

Sandorski, J. (1988). Organizacja Narodów Zjednoczonych u progu XXI wieku. Ruch Prawniczy, Ekonomiczny i Socjologiczny 50(3): 15-32. 
Skubiszewski, K. (1959). Umowy sojusznicze Polski a Karta Narodów Zjednoczonych. Ruch Prawniczy, Ekonomiczny i Socjologiczny 21(3): 1-16.

Skubiszewski, K. (1960). Odpowiedzialność międzynarodowa za pieniądz okupacyjny. Ruch Prawniczy, Ekonomiczny i Socjologiczny 22(2): 65-82.

Skubiszewski, K. (1960). Pieniądz na terytorium okupowanym. Studium prawnomiędzynarodowe ze szczególnym uwzględnieniem praktyki niemieckiej. Poznań.

Skubiszewski, K. (1962). Uprawnienie państw do samoobrony a Karta Narodów Zjednoczonych. Ruch Prawniczy, Ekonomiczny i Socjologiczny 24(4): 109-120.

Skubiszewski, K. (1967). Prawo wojny i neutralności w świecie współczesnym. Ruch Prawniczy, Ekonomiczny i Socjologiczny 29(1): 105-125.

Skubiszewski, K. (1972). Prawo PRL a traktaty. Ruch Prawniczy, Ekonomiczny i Socjologiczny 34(3): 1-18.

Skubiszewski, K. (1986). Wzajemny stosunek i związki pomiędzy prawem międzynarodowym i prawem krajowym. Ruch Prawniczy, Ekonomiczny i Socjologiczny 48(1): 1-16.

Symonides, J. (1966). Zasiedzenie w prawie międzynarodowym. Ruch Prawniczy, Ekonomiczny i Socjologiczny 28(1): 115-132.

Symonides, J. (1970). Znaczenie i istota prawna terytorium państwowego. Ruch Prawniczy, Ekonomiczny i Socjologiczny 32(1): 1-23.

Tyranowski, J. (1988). Zagadnienie reintegracji terytorium państwa a prawo ludu do samostanowienia. Ruch Prawniczy, Ekonomiczny i Socjologiczny 50(1): 1-20.

Wiewióra, B. (1960). Nawiązanie stosunków konsularnych a zagadnienie uznania. Ruch Prawniczy, Ekonomiczny i Socjologiczny 22(2): 53-64.

Wiewióra, B. (1963). Zagadnienia zwierzchnictwa terytorialnego w orzeczeniach Międzynarodowego Trybunału Sprawiedliwości z lat 1960-1962. Ruch Prawniczy, Ekonomiczny i Socjologiczny 25(2): 13-30.

Winiarski, B. (1930). O kodyfikacji prawa międzynarodowego. Ruch Prawniczy, Ekonomiczny i Socjologiczny 10(1): $144^{*}-159^{*}$.

Winiarski, B. (1931). Narodowość statków rzecznych i pierwsza konferencja prawa rzecznego. Ruch Prawniczy, Ekonomiczny i Socjologiczny 11(1): 28*-40*.

Winiarski, B. (1933). Hipoteka rzeczna w Polsce. Ruch Prawniczy, Ekonomiczny i Socjologiczny 13(2): $118^{*}-122^{*}$.

Winiarski, B. (1934). Przyczynek do rozważań nad stosunkiem prawa międzynarodowego do prawa rzymskiego. Ruch Prawniczy, Ekonomiczny i Socjologiczny 14(1): $11^{*}-24^{*}$.

Zaorski, R. (1963). Współpraca międzynarodowa w dziedzinie ochrony biologicznych zasobów Morza Bałtyckiego. Ruch Prawniczy, Ekonomiczny i Socjologiczny 25(1): 37-52.

\section{POZNAŃ STUDIES ON INTERNATIONAL LAW IN RUCH PRAWNICZY, EKONOMICZNY I SOCJOLOGICZNY}

Sum mary

The aim of the article is to provide an overview of the achievements of selected representatives of Poznan studies on international law, whose writings have been published in the previous volumes of the Ruch Prawniczy, Ekonomiczny i Socjologiczny [Journal of Law, Economics and Sociology]: Bohdan Winiarski, Alfons Klafkowski, Krzysztof Skubiszewski, Bolesław Wiewióra, Jan Sandorski, Jerzy Tyranowski, Tadeusz Gadkowski, and Anna Michalska. The article considers a selection of papers representative for the main directions of research conducted by three generations of international lawyers from Poznań's Department of Public International Law. The topics covered are as follows: the relationship between international law and national law, the sources of international law, international river law, international law of armed conflict and international responsibility, the law of international organizations, international protection of human rights, territory and recognition in international law, and nuclear law.

Keywords: public international law; Poznań studies on international law; Ruch Prawniczy, Ekonomiczny i Socjologiczny 
